IRSH 60 (2015), Special Issue, pp. I45-164 doi:I0.1017/S002085901 500036X (C) 2015 Internationaal Instituut voor Sociale Geschiedenis

\title{
The Dynamics of Race and Ethnicity in the US Coal Industry
}

\author{
J Oe William Trotter, JR \\ Center for Africanamerican Urban Studies and the Economy (CAUSE), \\ Department of History, Carnegie Mellon University \\ 5000 Forbes Avenue, Baker Hall 240, Pittsburgh, PA I5 2 I3, USA
}

E-mail: trotter@andrew.cmu.edu

\begin{abstract}
By the turn of the twenty-first century, scholars had transformed our understanding of class, race, and ethnicity in the rise and demise of the US coal industry. Under the twin impact of the modern Black Freedom Movement and the rise of the New Labor History, studies of American labor and race relations fragmented during the late twentieth century. Following the lead of pioneering labor historian Herbert Gutman, one influential body of scholarship resuscitated the early history of the United Mine Workers of America and accented the emergence of remarkable forms of labor solidarity across the color line during the industrial era. Before this scholarship could gain a firm footing in the historiography of labor and working-class history, however, social activist and labor scholar Herbert Hill forcefully argued that emerging emphases on interracial working-class cooperation downplayed the persistence of racial divisions even during the most promising episodes of labor unity. In significant ways, the Hill-Gutman debate fueled the florescence of whiteness studies and the myriad ways that both capital and labor benefitted from a racially stratified workforce. Based upon this rapidly expanding historiography of coalminers in America, this essay explores how the overlapping experiences of black and white miners established the foundation for modes of cooperation as well as conflict, but the persistence of white supremacist ideology and social practices repeatedly undermined sometimes heroic movements to bridge the chasm between black and white workers.
\end{abstract}

During the late twentieth century, a variety of studies transformed our knowledge of class, race, and ethnicity in the development of the US coal industry from its dramatic expansion after the Civil War through its rapid demise in the years after World War II. As early as 1968, social and labor historian Herbert Gutman urged scholars of the US working class to focus attention on the largely hidden history of interracial solidarity in the coal industry, particularly the role of the United Mine Workers of America (UMWA). In a variety of coalmining strikes in the northern and southern coalfields, including West Virginia and Alabama, Gutman underscored the emergence of unity among black and white miners. He also insisted that such 
actions represented viable alternatives to the system of ethnic and racial stratification in the workforce and community life of coalmining towns. ${ }^{\mathrm{I}}$

A plethora of studies soon followed Gutman's lead. ${ }^{2}$ These studies accented the occasions when class solidarity, spurred by the organizing activities of the UMWA, submerged the color line and challenged the authority of coalmine operators. Before such understandings of interracial solidarity in coalminers' lives and struggles could take hold, labor analyst Herbert Hill offered a stinging critique of the shortcomings of research inspired by Gutman's agenda for a new history of coalminers. Hill underscored the persistence of racial hostility within the coalmining workforce as well as the union despite moments of substantial evidence of unity across the color line. ${ }^{3}$

At about the same time, historian David Roediger and others produced studies emphasizing the salience of "white privilege". The notion of white privilege incorporated workers as well as elites across all sectors of the American economy, society, and politics, including the coercive powers of the state. ${ }^{4}$ Partly under the impact of Hill's critique and the emergence of "whiteness" scholarship, a fresh wave of studies offered increasingly complicated portraits of labor relations in the coalfields of industrial America. By the turn of the twenty-first century such studies largely rejected scholarly inquiries into "relations between black and white workers as either harmonious or antagonistic". ' Contemporary scholarship

I. Herbert Gutman, "The Negro and the United Mine Workers of America: The Career and Letters of Richard L. Davis and Something of their Meaning, I 890-I 900", in Julius Jacobson (ed.), The Negro and the American Labor Movement (Garden City, NY, 1968), pp. 49-I 27. Reprinted in Herbert Gutman, Work, Culture, and Society in Industrializing America: Essays in American Working-Class and Social History (New York, 1976), pp. I 2 I-208.

2. Early studies following Gutman's lead include: David A. Corbin, Life, Work, and Rebellion in the Coal Fields: The Southern West Virginia Miners, I880-I922 (Urbana, IL, I98I); Paul Worthman, "Black Workers and Labor Unions in Birmingham, Alabama, I897-1904", Labor History, Io (1969), pp. 375-407; Stephen Brier, "Interracial Organizing in the West Virginia Coal Industry: The Participation of Black Mine Workers in the Knights of Labor and the United Mine Workers, I880-1894", and Daniel P. Jordan, "The Mingo War: Labor Violence in the Southern West Virginia Coal Fields, 1919-1922”, both in Gary M. Fink and Merl E. Reed (eds), Essays in Southern Labor History (Westport, CT, 1977), pp. I 8-43, and I02-143.

3. Herbert Hill, "Myth-Making as Labor History: Herbert Gutman and the United Mine Workers of America", International Journal of Politics, Culture, and Society, 2 (1988), pp. I32-200; Nell Irvin Painter, "The New Labor History and the Historical Moment", International Journal of Politics, Culture, and Society, 2 (1989), pp. 367-370.

4. David Roediger, "History Making and Politics", International Journal of Politics, Culture, and Society, 2 (1989), pp. 371-372; idem, The Wages of Whiteness: Race and the Making of the American Working Class (London, I991); Peter Kolchin, "Whiteness Studies: The New History of Race in America", Journal of American History, 89 (2002), pp. I54-173; Eric Arnesen, "Whiteness and the Historians' Imagination", International Labor and Working Class History, 60 (200I), pp. 3-32; and responses to Arnesen's essay by James Barrett and others, ibid., pp. 33-80. 5. Daniel Letwin, The Challenge of Interracial Unionism: Alabama Coal Miners, I878-I92I (Chapel Hill, NC, 1998), p. 6. For more examples of studies in this vein see Karin A. Shapiro, 
underscores the distinctive experiences of each group; it acknowledges deep cleavages along the color line; and it notes how the rigors of life and labor in the coal industry (including the ongoing alliance of capital with the military might of the state) nonetheless helped to create a work culture and politics that cut across racial and ethnic divisions.

Drawing upon this expanding body of recent scholarship on the coal industry as well as upon my own earlier research on coalminers in southern West Virginia, this essay addresses a series of debates in the historiography of coalminers in America. First and most important, it confronts the class-race debate ignited by Herbert Hill when he challenged Gutman's interpretation of labor and race relations in the US coal industry. This article reinforces Hill's emphasis on the deep racial divide in both the coalmining workforce and the union, but it also accents the powerful role that the UMWA played in galvanizing interracial unity compared with other industrial unions such as the steelworkers and meatpackers at the time.

While this article identifies the color line as the most enduring and pronounced division among coalminers in industrial America, it rejects the conclusion that the entrenched racial hostility of white workers, employers, and the state largely obliterated the influence of black miners over their own lives. On the contrary, African-American miners forged a variety of strategies for shaping their own experience in the coalfields. Their efforts included the construction of their own coalmining communities as well as membership in the UMWA when and where possible. In other words, despite powerful recent critiques decrying the limits of an entire generation of scholarship accenting the self-activities of poor and working-class people, ${ }^{6}$ this essay underscores the need for ongoing if more nuanced treatments of this indelible thread in black workers' culture and politics.

Black miners' history was by no means as uniform or monolithic as sometimes suggested in labor and working-class studies. In addition to highlighting the "agency" of black workers, this study addresses questions of variation across regions as well as time in the lives of black no less than white miners. African Americans first entered the coalfields as enslaved people before the Civil War. In the wake of emancipation, they encountered intense labor exploitation and inequality in the Alabama fields, a measure of

A New South Rebellion: The Battle against Convict Labor in the Tennessee Coalfields, $1871-1896$ (Chapel Hill, NC, 1998); Brian Kelly, Race, Class, and Power in the Alabama Coalfields, I908-2I (Urbana, IL, 200I); Ronald L. Lewis, Black Coal Miners in America: Race, Class and Community Conflict, 1780-1980 (Lexington, KY, I987); Crandall A. Shifflett, Coal Towns: Life, Work, and Culture in Company Towns of Southern Appalachia, I880-1960 (Knoxville, TN, 1991); Joe William Trotter, Jr, Coal, Class, and Color: Blacks in Southern West Virginia, I9I5-1932 (Urbana, IL, I990).

6. For a provocative critique of this notion see Walter Johnson, “On Agency”, Journal of Social History, 37 (2003), pp. I I 3-I 24. 
equality in southern West Virginia, and a pattern of stiff resistance and exclusion in Pennsylvania, Ohio, and Illinois.

Finally, this essay calls attention to the ethnic fragmentation of the immigrant and American-born white coalmining workforce. Before the gradual emergence of the UMWA, substantial conflict characterized the life and labor even of English-speaking miners. Until the I960s, however, a voluminous immigration historiography tended to homogenize the experiences of diverse immigrant groups from the British Isles English, Scottish, and Welsh, although not of the Irish. According to this body of scholarship, British migrants were "absorbed into the general mass of native [American] citizens", and largely lost their identity "almost immediately". It was the arrival of "new immigrants" from southern, central, and eastern Europe that touched off virulent relations among white workers. $^{7}$

During the late twentieth century, immigration historians shifted their attention away from a preoccupation with the "assimilation" of migrants and immigrants into the established culture, politics, and society of the United States. New research focused on conflict and the persistence of old-world forms of politics and institutions in the rapidly industrializing nation. ${ }^{8}$ In sum, informed by these larger currents in US labor, ethnic, and social history, this essay explores the numerous ways that perceived ethnic and racial differences shaped miners' experiences, while emphasizing the distinctive history of African-American coalminers and their communities based upon the pervasive ideology and practices of white supremacy.

\section{WHITE MINERS'ETHNICITY, CONFLICT, AND SOLIDARITY}

During the antebellum years, the US coal industry gradually developed on the basis of British immigrant miners in the anthracite district of Pennsylvania. By the I 840 , some 6,800 coalminers produced nearly 2 million tons of coal in the United States. In the antebellum South, namely Virginia and Alabama, enslaved African-American workers supplemented the early white

\footnotetext{
7. John J. Bukowczyk, "Introduction, Forum: Thomas and Znaniecki's The Polish Peasant in Europe and America", Journal of American Ethnic History, I6 (1996), pp. 3-1 5; Ronald L. Lewis, Welsh Americans: A History of Assimilation in the Coalfields (Chapel Hill, NC, 2008), p. 4. For helpful theoretical and empirical assessments of assimilationist theory, see also, respectively, Alice O'Connor, Poverty Knowledge: Social Science, Social Policy, and the Poor in Twentieth-Century US History (Princeton, NJ, 200I), and Mildred A. Beik, The Miners of Windber: The Struggles of New Immigrants for Unionization, I 8905-I930s (University Park, PA, I996).

8. Jon Gjerde, "New Growth on Old Vines - The State of the Field: The Social History of Immigration to and Ethnicity in the United States", Journal of American Ethnic History, I 8 (1999), pp. 40-65. For an initial synthesis of this scholarship, see John Bodnar, The Transplanted: A History of Immigrants in Urban America (Bloomington, IN, 1985).
} 
coalmining workforce. ${ }^{9}$ Following the American Civil War, the US coal industry dramatically expanded. In the eastern Pennsylvania anthracite region alone, coal production rose from $\mathrm{I} 3$ million tons in $\mathrm{I} 870$ to 54 million tons in I9I0. At the same time, the anthracite coalmining workforce increased from 36,000 to over 140,000 miners. In addition to American-born migrants from nearby farms and rural settlements, immigrants from England, Scotland, Wales, and Ireland dominated the early postbellum coalmining workforce. ${ }^{10}$

Nationality, race, and ethnic differences produced significant levels of economic competition, as well as social and political conflict in the US coal industry. While diverse English-speaking immigrants from the British Isles and their American-born counterparts would soon develop forms of solidarity that mitigated their differences, this outcome was by no means a foregone conclusion. In the Mahoning Valley region of Ohio, the Welsh not only spoke their own language, they also "conducted their union meetings entirely in Welsh". In I 874, according to an Illinois miner, each ethnic group forged its own separate institutional and community life: "The English have the St Georges, the Scotch the St Andrews, the Welsh the S. David's, and the Irish the St Patrick's." I

Despite evidence of nationality and ethnic conflicts in the early postbellum coalfields of the United States, British- and American-born miners soon developed bonds of solidarity in their escalating encounters with the owners of the coalmines. During the final decades of the nineteenth century, they forged a collective identity around their work in the mines, partly honed in the fires of British collieries before migration to America. In I 87 I John Hall, an English-born miner, underscored the link between his work as a miner in the United States and his home in England. "I am a miner [...]. I was a miner in the old country, from which I migrated in I 848. I have mined coal in Pennsylvania and also western Virginia. I began mining work when eight years old." ${ }^{2}$

British miners viewed themselves as fiercely "proud", "literate", and "skilled" craftsmen. They also described themselves as "experienced" and independent "contractors, not mere wage earners". In his groundbreaking study of Welsh miners in the US, historian Ronald Lewis provides a close and detailed transnational portrait of how the British miners "transferred their scientific knowledge of underground mining to America as well as

9. Priscilla Long, Where the Sun Never Shines: A History of America's Bloody Coal Industry (New York, 1989), pp. 3-5, and I9-23. See also Ronald L. Lewis, Coal, Iron, and Slaves: Industrial Slavery in Maryland and Virginia, I7IS-I865 (Westport, CT, I979); Robert S. Starobin, Industrial Slavery in the Old South (New York, 1970).

I0. Long, Where the Sun Never Shines, pp. 3-5, and 56-57.

I I. Lewis, Welsh Americans, pp. ix-x, and I-9.

I 2. Ibid., pp. 5 I-90; John Hall is quoted from Long, Where the Sun Never Shines, p. 7. 
their practical skills as craftsmen". ${ }^{3}$ Skilled "pick miners", as they were sometimes called, not only exercised considerable control over their own daily production of coal and drove up the cost of their labor, they also largely set their own work schedules. As such, they made decisions, too, about the time devoted to their own leisure, home, business, community, and organized labor activities away from the pits. Indeed, some miners earned enough money to purchase and furnish their own homes.

Until the closing decades of the nineteenth century, English-speaking immigrant and American-born colliers made up the majority of the total coalmining workforce. In addition to pioneering such widely dispersed coalfields as those in the eastern Pennsylvania anthracite district, they initiated coal production in the emerging bituminous coalfields of western Pennsylvania, Ohio, Illinois, and Indiana; the Appalachian South; and the western states of Colorado, Washington, and parts of Wyoming. ${ }^{14}$ In the Colorado coalfields, the number of coalminers increased from no more than about I, 500 in I 870 to a peak of nearly I6,000 in I 910 . In Colorado and elsewhere, British, Irish, and Welsh miners formed the artisan core of the initial coalmining workforce. ${ }^{\text {Is }}$

By the turn of the twentieth century, a variety of forces gradually transformed the character of the US coal industry and undercut the pivotal role of English-speaking and American-born white miners within the workforce. In both the anthracite and bituminous coalfields, the British and American-born "aristocrats" of the coalmining workforce confronted increasing challenges to their precarious hegemony. As early as I 890 , introduction of the coal-undercutting machine dramatically reduced demand for experienced pick miners and opened the door for the recruitment of a large, ethnically and racially diverse, and less skilled hand-loading workforce. The percentage of the coal mechanically undercut for loading increased to nearly 25 per cent in 1900 and to over 80 per cent by 1930 . The new machinery increased the daily output of the individual miner from 2.57 tons in $189 \mathrm{I}$ to $3.7 \mathrm{I}$ tons by the beginning of World War I. ${ }^{\mathrm{I}}{ }^{6}$

I3. John H.M. Laslett (ed.), The United Mine Workers of America: A Model of Industrial Solidarity? (University Park, PA, I996), p. I4; Lewis, Welsh Americans, pp. 59-60, I 20-I 2 I.

I4. John H.M. Laslett, "Introduction: 'A Model of Industrial Solidarity': Interpreting the UMWA's First Hundred Years, I890-1990", in idem, The United Mine Workers of America, pp. I-25; idem, Nature's Noblemen: The Fortunes of the Independent Collier in Scotland and the American Midwest, I855-I889 (Los Angeles, CA, I983), pp. I-9; Maier B. Fox, United We Stand: The United Mine Workers of America I 890-1990 (Washington DC, I990), pp. 21-23, 56-74, and 82-Iог; Perry K. Blatz, Democratic Miners: Work and Labor Relations in the Anthracite Coal Industry, I875-1925 (Albany, NY, I994), pp. I-35.

I 5. Thomas G. Andrews, Killing for Coal: America's Deadliest Labor War (Cambridge, MA, 2008), pp. 95-96, and 102-103.

16. Keith Dix, What's A Coal Miner to Do? The Mechanization of Coal Mining (Pittsburgh, PA, I988), pp. 6-7, 28-32, and 217 . 


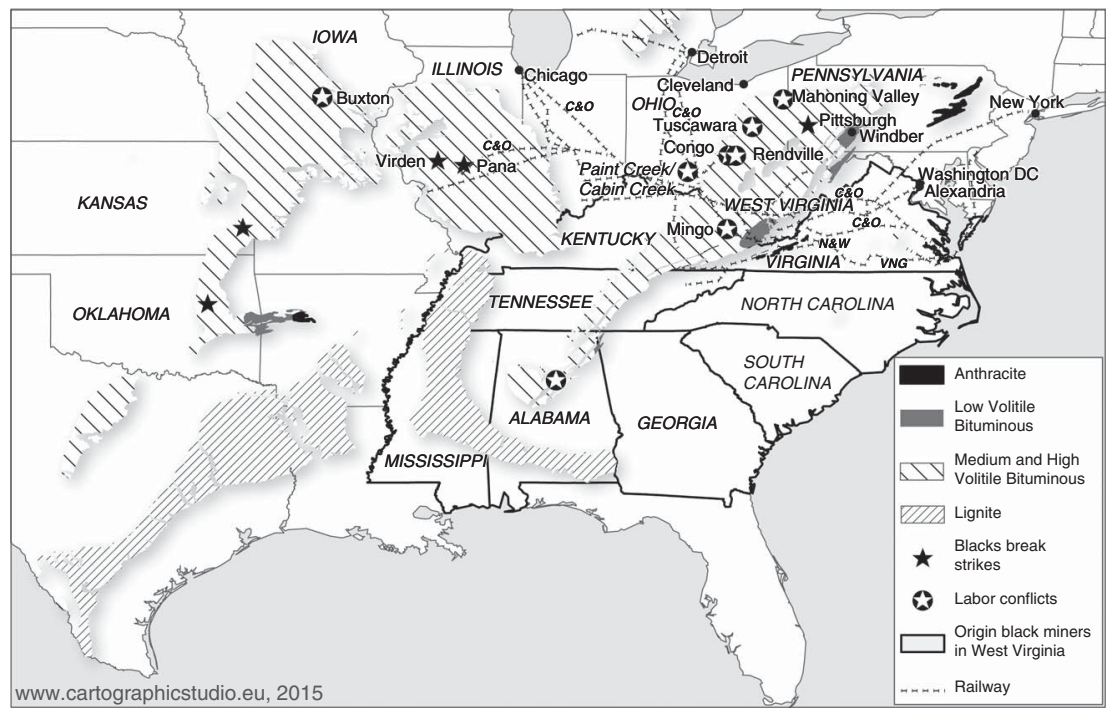

Figure I. The US coal industry.

Closely intertwined with the expansion of the undercutting machine was massive migration from rural America as well as immigration from eastern, central, and southern Europe to meet the coal industry's growing demand for low-wage hand loaders and general laborers. In rapid succession, operators recruited trainloads of Italian, Slav, Polish, Hungarian, and other new European immigrants for work in the coalmines. Founded in I 897, for example, the coal town of Windber, Pennsylvania, had deep roots in the new immigration. In I910, according to historian Mildred Beik, four southern, central, and eastern European groups made up nearly 85 per cent of the town's total foreign-born population and about 45 per cent of its total population. ${ }^{17}$

Established British- and American-born English-speaking white miners resisted the impact of both technological changes and massive southern, central, and eastern European immigration on their work, livelihood, and communities in coalmining towns. British colliers not only openly disdained the new workers as "ignorant", untrained miners who threatened their safety underground, they also regarded new immigrant culture,

17. Beik, The Miners of Windber, pp. xx-xxx, and I-s I; idem, "The UMWA and New Immigrant Miners in Pennsylvania Bituminous: The Case of Windber”, and John H.M. Laslett, “'A Parting of the Ways': Immigrant Miners and the Rise of Politically Conscious Trade Unionism in Scotland and the American Midwest, I865-1924", in Laslett, The United Mine Workers of America, pp. 320-325, and 417-437. 
work habits, and adherence to Catholicism as a threat to Anglo-Saxon Protestantism. As historian John H.M. Laslett notes, established British colliers responded to the increasing influx of new people with "a mixture of condescension and contempt". In some cases, these workers upped sticks and moved west, describing the new immigrants in nativistic terms as the "Slav invasion". Violence against Slavs by earlier British and particularly Welsh miners resulted in the Latimar Massacre on io September I 897, when armed coal company guards murdered nineteen Slav strikers in cold blood in the anthracite coalfields of Pennsylvania. ${ }^{18}$

After a period of intense economic, social, and political resistance to the new immigrants, British colliers gradually accepted Italians, Poles, Slavs, and other immigrants into the United Mine Workers of America (UMWA) union, organized in I 890. By World War I, the UMWA had organized old and new immigrants of European descent as well as growing numbers of African Americans. Following the massacre of Slav miners, noted above, Welsh miners joined their Slav brothers and walked out under the banner of the UMWA. Although challenged by the rise of the militant Industrial Workers of the World (IWW), founded in I905, the UMWA became the most ethnically and racially diverse union in the US labor movement. While the UMWA faced an ongoing uphill battle against the coal operators' immense capital and police power, as well as struggling for control over company-owned towns, organized miners achieved significant success in the bituminous coalfields of western Pennsylvania, Ohio, Illinois, and Indiana, though they were far less successful in the anthracite fields of eastern Pennsylvania. ${ }^{19}$

Despite the increasing movement of new immigrants into the coalfields as well as into the UMWA, they nonetheless faced stiff barriers breaking into the higher-skilled, managerial, and supervisory jobs both before and after joining the union. They also confronted obstacles, including ethnic segregation in the housing, institutional, cultural, and political life of coalmining towns. At the Windber mines, new immigrants constituted 99 per cent of all miners in I9I0, but they made up only about io per cent of mine foremen and assistant foremen. Company housing policy also separated English-speaking and earlier immigrant miners from their new immigrant counterparts. At the same time, the Berwind-White Coal Company reinforced the growth of nativist organizations like the Patriotic Order of the Sons of America during the opening decades of the twentieth century and the $\mathrm{Ku}$ Klux Klan during the I920s. Furthermore, English-speaking residents also dominated the town's government, fire, and police departments. ${ }^{20}$

18. Lewis, Welsh Americans, pp. 236-237; Blatz, Democratic Miners, pp. 55-60.

19. Lewis, Welsh Americans, pp. 238-239; Isaac Cohen, "Monopoly, Competition, and Collective Bargaining: Pennsylvania and South Wales Compared", in Laslett, United Mine Workers of America, pp. 4I 5-4I 6; Long, Where the Sun Never Shines, pp. 248-249, and 32 I-323.

20. Beik, "The UMWA and New Immigrant Miners in Pennsylvania Bituminous", p. 329. 


\section{AFRICAN AMERICANS AND THE LIMITS OF WORKING-CLASS UNITY}

The incorporation of new immigrant miners into the labor movement of coalmining towns produced some (though insufficient) benefits, but it was the color line that emerged as the most salient social division that fragmented the coalmining working class. Nonetheless, similar to the larger US coal industry, the experiences of African-American miners varied considerably from region to region and across time. Distinct patterns of "race, class, and community conflict" emerged in the coalfields of "Deep South" Alabama and the Chesapeake region as well as in the north-east and mid-west. ${ }^{21}$ As alluded to above, the first generation of black miners entered the coal industry as enslaved workers in eastern Virginia, the Kanawha Valley, western Virginia, and north-central Alabama. Enslaved antebellum miners gave way in the postbellum years to a predominantly black prison "convict" coalmining labor force on the one hand and a sharply racially stratified free coalmining working class on the other.

Free black miners faced a strictly enforced lower wage rate than white workers. They also encountered discriminatory coal-weighing scales based on race, and a racially exploitative "contract" labor system. In the contract arrangement, regular white coal loaders hired black workers as lowly paid helpers and largely passed on the most arduous work of coalmining labor to their black counterparts. Partly because of this anti-black racial imperative, particularly in the coal strikes of I 894 and I908, coal operators effectively used the "social-equality" issue as a wedge to divide workers and undermine public support for the union cause. Thus, in the Deep South coalfields, the convict lease system only disappeared during the I 890 and the early twentieth century; and it was not until the I930s that white workers gradually challenged the "social-equality" notion and forged stronger ties with black miners across the color line. ${ }^{22}$

Whereas black workers confronted extreme forms of exploitation in the Alabama coal industry, they were largely excluded from the anthracite

21. Lewis, Black Coal Miners in America, pp. iv-xv.

22. Ibid., pp. viii-xv; Lewis, Coal, Iron, and Slaves, pp. 3-10; Letwin, The Challenge of Interracial Unionism, pp. I-30; Kelly, Race, Class, and Power in the Alabama Coalfields, pp. 3-1 5. In her groundbreaking study of resistance against convict labor in Tennessee, historian Karin Shapiro shows how black and white miners forged greater interracial solidarity in the east Tennessee coal towns of Coal Creek, Briceville, and Oliver Springs than they did in the southeastern town of Tracy City. See Shapiro, A New South Rebellion, pp. i 2-1 3. Coal companies provided wider screens for weighing coal mined by blacks than they did for whites, thus creating a racial differential in pay. Such practices reinforced the idea that white men were both materially and socially "superior" to black workers. Thus, any evidence of black-white solidarity through labor unions flirted with the idea of social equality of all workers and threatened white-worker privileges such as discriminatory weighing practices. See Lewis, Black Coal Miners in America, p. 47. 
region of Pennsylvania and only slowly moved into the bituminous fields of western Pennsylvania, Ohio, Illinois, Iowa, and Indiana in small numbers. However, as diverse groups of white miners slowly bridged their differences, created more potent forms of labor solidarity, and walked out on strike for better pay, living, and working conditions in coal towns, northern coal operators turned increasingly to black workers as strikebreakers. Beginning during the i 880 s, coal companies regularly imported black workers to break strikes in the Pittsburgh district, the Tuscarawas Valley of Ohio, Virden and Pana in Illinois, and parts of Oklahoma and Kansas. In the small coalmining town of Buxton, Iowa, the coal company imported southern black workers to break the strike among white miners during the I 890 s. Blacks soon became the single largest ethnic group in the town's workforce before the town's demise during the i 920 s. $^{23}$

In the Pittsburgh district, strikebreaking persisted into the I920s (including most notably the coal strikes of 1922, 1925, and 1927). Strikebreaking entailed a substantial incidence of violence between striking white workers and African Americans as well as between white workers, company guards, and police. As economists Abram L. Harris and Sterling Spero noted in their historical study, The Black Worker (1931), in western Pennsylvania between September 1927 and February 1928 the results of African-American strikebreaking activities "were written largely with violence, bloodshed, loss of life, and the destruction of property". Similar to the earlier reactions of British miners to their southern, central, and eastern European counterparts, old and new white miners of various nationalities and ethnicities treated African-American migrants as a "foreign invasion" of their "homes". During labor disputes, white workers often declared in the face of black workers, "I do not mind the white scab, but I be damned if I will stand for a Negro scab." For their part, black strikebreakers sometimes boldly retorted, "You would not work with me before the strike. Now I have your job and I am going to keep it." 24

Despite the recurring use of black strikebreakers in the coalfields, the United Mine Workers nonetheless reached out to African Americans and opened its doors to black workers earlier than steel, meatpacking, and other mass production industries. From its founding in I 890 , the UMWA pledged "to unite in one organization, regardless of creed, color or nationality, all workmen $[\ldots]$ employed in and around coal mines". Moreover, the union

23. Sterling D. Spero and Abram L. Harris, The Black Worker (193 I; repr. New York, I968), pp. 2 I0-2 I 3; Bruce Nelson, Divided We Stand: American Workers and the Struggle for Black Equality (Princeton, NJ, 2002), p. I67; Dorothy Schwieder, Joseph Hraba, and Elmer Schwieder, Buxton: Work and Racial Equality in a Coal Mining Community (Ames, IA, 1987), pp. 3-1 2, 209. See also Dorothy Schwieder, Black Diamonds: Life and Work in Iowa's Coal Mining Communities, I895-1925 (Ames, IA, I983).

24. Spero and Harris, The Black Worker, p. 233; Nelson, Divided We Stand, p. I67. 
sought to insure equality of work opportunities among miners in practice. The UMWA constitution included a clause stating that, "No member in good standing who holds a dues or transfer card shall be debarred or hindered from obtaining work on account of race, creed or nationality." African-American membership in mine unions increased from about I,000 at the union's founding to about 5,000 , before declining during the mid-r 920 . Black miners not only joined the union, they participated in large-scale strikes in the northern and southern coalfields, including the bloody confrontations in Alabama in 1908 and West Virginia (particularly the Paint Creek Cabin Creek Strikes of I9I 2-I9I 3 and the Mingo Coal War of I92I). ${ }^{25}$

Coalminers developed some of the most remarkable episodes of interracial as well as interethnic solidarity in the US labor movement. The UMWA soon employed blacks as union officers, including locals with predominantly immigrant members. African-American facility in English made them preferred representatives in some locals with majority immigrant miners. In I 89I, the Rendville, Ohio, miner Richard L. Davis was elected to the executive board of the UMWA District Six (Ohio). He held the Ohio post for six years, and in I 896 and again in I 897 he was elected to the national executive board, the highest position ever held by an African American in the UMWA. Davis's influence was felt at the local, regional, and national levels. He advised miners during bitter industrial disputes in West Virginia, western Pennsylvania, and Alabama as well as Ohio. In I 892, for example, when owners sought to segregate one mine in Rendville by using black laborers exclusively, paying those workers lower wages and forcing them to work under poorer conditions than had been the case in integrated mines, Davis rallied black and white workers against the company's effort to divide workers along racial lines.

In another instance Davis opposed the development of segregationist policies in Congo, Ohio. After calling attention to segregated housing, he observed a similar pattern in the mines and urged an end to such racial stratification. Davis resolutely and consistently opposed exclusionary hiring practices, advocated the election of blacks to leadership positions in the union, and protested white miners' discriminatory attitudes and behavior toward black workers. On one occasion, he rebuked his white counterparts for referring to black men in derogatory language, "I assure anyone that I have more respect for a scab than I have for a person who refers to the negro in such way, and God knows the scab I utterly despise."26

25. Spero and Harris, The Black Worker, pp. 356-357. See also Letwin, The Challenge of Interracial Unionism, pp. 89-1 23; Corbin, Life, Work, and Rebellion in the Coal Fields, pp. 45-46, 65-77, 87-I0I; Shapiro, A New South Rebellion, pp. 31-32, 229-230.

26. Richard L. Davis's coalmining career is well-documented in the columns of the United Mine Workers' Journal (UMWJ) and the National Labor Tribune (NLT). See also Gutman, "The Negro and the United Mine Workers of America". 
Although the UMWA forged some of the nation's most significant movements for labor solidarity across the color line, it nonetheless failed to stem the development of racially and ethnically divided coalmining towns. Segregated and unequal work, living, family, and community environments greeted black miners across regions and from place to place within the coalfields of the North and South. According to Spero and Harris:

$[\ldots]$ the most frequent complaint one got from the Negro unionist in the coalfields was his inability to use his union card at some mines where the employment of a Negro had caused the white union miners to strike, or where it was believed by the operators that the employment would cause a strike.

Black miners regularly complained of the union's “inability or unwillingness to draw any distinction between the absence of racial discrimination in constitutional principle and the appearance of it in every day fact" ${ }^{27}$

\section{MINING ALONG THE COLOR LINE: THE CASE OF SOUTHERN WEST VIRGINIA ${ }^{28}$}

A closer look at the southern West Virginia coalfields reveals both the promise and limits of coalmining work, unionization, and efforts to secure the full emancipation of the black worker during the industrial era of US history. African Americans gained a firmer (but still precarious) footing in the mines of southern West Virginia than they did further south and north. Beginning slowly during the Civil War and early postbellum years, black migration to the Mountain State accelerated during the late nineteenth and early twentieth centuries. Under the impact of the expanding bituminous coal industry, the black population dramatically increased, rising from 25,800 in I 880 , to over 64,000 in I910, and to nearly i I 5,000 in 1930 . At a time when most industrial firms in the nation excluded black workers from employment, both the railroad and coal industries hired large numbers of African Americans to open up the bituminous coalfields of southern Appalachia. African Americans helped to lay track for the Chesapeake \& Ohio, the Norfolk \& Western, and the Virginian railway lines. Work on the Chesapeake \& Ohio line also produced the black folk hero John Henry. Most important, however, growing numbers of black railroad men remained behind as part of the expanding coalmining labor force. Blacks made up over 20 per cent of West Virginia's total coalmining labor force from the i 890 s through the early twentieth century. ${ }^{29}$

27. Spero and Harris, The Black Worker, pp. 336-337.

28. For this analysis of coalmining in southern West Virginia, I am indebted to the University of Illinois Press for permission to reprint portions of my book, Coal, Class, and Color: Blacks in Southern West Virginia, I9I5-I932.

29. James T. Laing, "The Negro Miner in West Virginia" (Ph.D. dissertation, Ohio State University, 1933), pp. 64-69; J.M. Callahan, Semi-Centennial History of West Virginia 
The nearby states of Virginia, Kentucky, and Tennessee sent the lion's share of black migrants to West Virginia before World War I. During the war and its aftermath, however, rising numbers of black migrants from the Deep South states of Alabama, Georgia, and Mississippi supplanted the Upper South sources of black migrants. Based substantially on the labor of rising numbers of black workers, coal production increased from less than 5 million tons in 1885 to nearly 40 million in the southern counties of the state alone by i910. Although the industry would experience recurring upswings and downswings in the demand for coal, southern West Virginia mines produced over $\mathrm{I} 20$ million tons in 1925 .

Important social, cultural, and political factors reinforced the attractiveness of West Virginia as a target of black migrants. Racial lynchings were fewer, educational opportunities were greater, and voting was not restricted by race, unlike elsewhere in the South. Although it frequently overstated the case, during the I920s the Bureau of Negro Welfare and Statistics (BNWS), a state agency, repeatedly emphasized the political and social attractions of West Virginia. ${ }^{30}$

In addition to the economic conditions from which they came, the recruitment and advertising campaigns of coal companies provided important stimuli to black migration. At the height of World War I, such advertising intensified. Professional labor recruiters for the coal companies encouraged southern blacks to move to the coalfields. Coal companies also enlisted the support of middle-class black leaders. Especially important was the regional black weekly, the McDowell Times, which circulated in West Virginia and nearby Virginia. During World War I, the McDowell Times editorially proclaimed: "Let millions of Negroes leave the South, it will make conditions better for those who remain." ${ }^{1}$ In lengthy articles, the McDowell Times celebrated the movement of blacks into the various coal camps, such as Glen White, Raleigh County:

The old saying that "All roads lead to Rome" surely has its modern analogy [...] "All railroads seem to lead to Glen White" for every train drops its quota of colored folks who are anxious to make their homes in the most beautiful spot in the mining district of West Virginia. ${ }^{32}$

The McDowell Times columnist, Ralph W. White, stated simply: “To one and all of them we say WELCOME." 33

(Charleston, WV, I913); A.A. Taylor, The Negro in the Reconstruction of Virginia (Washington DC, I926); Corbin, Life, Work, and Rebellion in the Coal Fields, ch. 7.

30. West Virginia Bureau of Negro Welfare and Statistics (hereafter, WVBNWS), Biennial Report (Charleston, WV, 1921-1922), p. 5, and Biennial Report (Charleston, WV, 1925-I926), p. 8.

31. "The Exodus", McDowell Times, i 8 August 1916. Unless indicated otherwise, none of the newspaper articles quoted here have a specified author.

32. "Southern Exodus in Plain Figures", McDowell Times, I December I916.

33. Ralph W. White, "Another Lesson [...]”, McDowell Times, 20 July 1917. See also "Colored Folks Enjoying Universal Industrial and Social Advancement”, McDowell Times, 28 July i9 7. 
Despite the optimistic portrayals of the McDowell Times, a substantial degree of private and public coercion underlay the recruitment of black labor. Operators often advanced the migrants transportation fees, housing, and credit at the company store. Using privately employed detectives from Baldwin-Felts, a private agency infamous for its brutal anti-labor activities, some coal operators were notorious for their violent control of black workers. ${ }^{34}$ In I917, the West Virginia legislature enacted a law to "prevent idleness and vagrancy [...] during the war and for six months thereafter. All able bodied men between 18 and 60 years of age, regardless of color, class or income must toil thirty-five hours each week to support themselves and their dependents." ${ }^{35}$ Moreover, West Virginia had passed a prohibition law in I9I4, and some of the prohibition arrests, convictions, and sentences to hard labor on county road projects were scarcely veiled efforts to discipline and exploit the black labor force. Even the local black weekly soon decried the arrest of what it condescendingly called "a lot of ignorant men and depriving their families of support for months and in some cases years". According to the state commissioner of prohibition, southern West Virginia had the highest incidence of arrests, convictions, and sentences to hard labor on county road projects. ${ }^{36}$

Although some black miners felt the impact of public and private coercion, most migrants chose southern West Virginia voluntarily, using their network of kin and friends to get there. After arriving, they often urged their southern kin and friends to join them. Acute contemporary observers understood the process. In his investigation of the great migration, the US attorney for the Southern District of Alabama reported that at least io per cent of those who had left had returned, but half of the returnees had come back for relatives and friends. "It is returned negroes who carry others off." 37

34. United States Senate Committee on Interstate Commerce, Conditions in the Coal Fields of Pennsylvania, West Virginia, and Obio (Washington DC, 1928). For excerpts from the committee hearings, see United Mine Workers Journal, I March I928. See also “Testimony of J.H. Reed”, in United States Senate Committee on Education and Labor, West Virginia Coal Fields (Washington DC, I92I), pp. 479-482.

35. "Idlers between Ages of Eighteen and Sixty Will Be Forced to Work", McDowell Recorder, 25 May 1917. See also T. Edward Hill, "Loafers and Jonahs", McDowell Times, 25 May 1917; "Dig Coal or Dig Trenches is the Word to the Miner", Raleigh Register, I2 July I9I7.

36. Quote from: "Educate All the People”, I6 April i9 I s. See also "To Whom it May Concern", 29 January I91 5; "Good People of McDowell County Outraged”, I7 May I918, all in McDowell Times; State Commissioner of Prohibition, Biennial Report (Charleston, WV, I92 I-I 922 ).

37. Robert N. Bell, US Attorney, Northern District of Alabama, to US Attorney General, 25 October 1916; and Alexander D. Pitts, US Attorney, Southern District of Alabama, to Samuel J. Graham, US Assistant Attorney General, 27 October 1916, both in National Archives, Washington DC, Department of Justice, Record Group No. 60, Straight Numerical File No. 182363. See also Otis Trotter, Keeping Heart: A Memoir of Family Struggle, Race, and Medicine (Athens, $\mathrm{OH}, 20 \mathrm{I} 5$ ), Introduction; Salem Wooten, interview by author, 25 July 1983 ; 


\section{COAL LOADING}

Coal loading was the most common, difficult, and hazardous job in the mine. Yet, black men often preferred it because it paid more than other manual labor jobs and "provided the least supervision with the greatest amount of personal freedom in work hours". ${ }^{8}$ As one black miner recalled, coal loaders could make more money because they were paid by the ton, and could increase their wages by increasing their output. ${ }^{39}$ On the other hand, while average wage rates for coal loading were indeed higher than those for most outside jobs, inside work was subject to greater seasonal fluctuation and greater health hazards than outside positions. ${ }^{4}$ Although coal loading was classified as unskilled work, it did require care and skill. It took over an hour of preparation before the miner could lift his first shovel of coal. The miner deployed an impressive repertoire of skills: the techniques of dynamiting coal, including knowledge of various gases and the principles of ventilation; the establishment of roof supports to prevent dangerous cave-ins; and the persistent canvassing of mines for potential hazards. Referring to the training he received from his brother, Salem Wooten recalled: "The first thing he taught me was [...] my safety, how to set props and posts. Wood posts were set up to keep the slate and rocks from caving in on you $[\ldots]$ safety first." ${ }^{\mathrm{I}}$

Wooten's brother also taught him techniques for blasting coal: how to drill holes with an auger and place several sticks of dynamite in them properly; how to judge atmospheric conditions and be accurately sensitive, not only to his own safety, but also to the safety of fellow workers. Salem Wooten also learned the miner's distinctive vocabulary of terms, such as "bug dust", particles of coal remaining after machines undercut the coal; "kettlebottom", a huge fossilized rock, responsible for numerous injuries and even deaths when it dislodged from the roof of mines; and the frequently shouted "Fire! Fire in the Hole!", warning fellow workers of an impending dynamite blast. ${ }^{42}$ In small numbers, African Americans also

Thelma O. Trotter, conversation with author, I August 1983; Solomon Woodson, conversation with author, 9 November 1985 .

38. James T. Laing, "The Negro Miner in West Virginia", Social Forces, I4 (1936), pp. 416-422, 4I 8 .

39. North Dickerson, interview by author, 28 July 1983 .

40. Laing, “The Negro Miner” (1936); Dickerson, interview by author, 28 July 1983.

4I. Wooten, interview. Similar statements were made in other interviews: Charles T. Harris, interview by author, I 8 July 1983; Leonard Davis, interview by author, 28 July 1983; Watt Teal, interview by author, 23 July 1983 . For general insight into the miners' work, see Carter Goodrich, The Miner's Freedom (1925; repr. New York, I97I), and Keith Dix, Work Relations in the Coal Industry: The Handloading Era, I880-1930 (Morgantown, WV, I977), chs I and 2.

42. Wooten, interview. While some scholarly accounts refer to the particles left by the undercutting machine as "duck dust", black miners used the term "bug dust". See Laing, "The Negro 
worked in skilled positions as machine operators, brakemen, and motormen. Labor advertisements sometimes specified the broad range of jobs available to African Americans: "Coal Miners, Coke Oven Men, Day Laborers, Contract Men and Helpers, Motormen, Track Layers, Machine Runners, Mule Drivers, Power Plant Men, and other good jobs to offer around the mines". 43

However skillful black loaders may have become, coal loading took its toll on the health of black men. Some men literally broke themselves down loading coal. Pink Henderson painfully recalled:

My daddy got so he couldn't load coal. He tried to get company work [light labor, often on the outside] but the doctor turned him down, because he couldn't do nothing. He done broke his self down [...] My brothers done the same thing. They used to be the heavy loaders. ${ }^{44}$

Moreover, all coal loaders, black and white, careful and careless, were subject to the inherent dangers of coalmining: black lung, then commonly called "miners' asthma”, the slow killer of miners caused by the constant inhalation of coal dust; explosions, the most publicized and dramatic cause of miners' deaths; and slate falls, the largest and most consistent killer of miners. All miners and their families had to learn to live with the fear of death, although few fully succeeded. As one black miner and his wife recalled: "That fear is always there. That fear was there all the time, because $[\ldots]$ you may see [each other] in the morning and never [see each other] any more in the flesh." 45

Miner" (1933), p. I71; Dix, What's a Coal Miner to Do?, ch. I; and Goodrich, The Miner's Freedom, p. xx.

43. For examples of advertisements see: "Safety First"; "Go North"; "Wanted"; "Employment Office"; "Wanted Sullivan Machine Men", Logan Banner, 8 June 1923. For African Americans in skilled positions see: interview with William M. Beasley, 26 July 1983; interview with Roy Todd, I 8 July 1983; Dix, Work Relations in the Coal Industry, ch. I; Laing, "The Negro Miner" (1933), pp. 264-265; Price V. Fishback, "Employment Conditions of Blacks in the Coal Industry, 1900-1930" (Ph.D. dissertation, University of Washington, I983), ch. 6.

44. Interview with Pink Henderson, I 5 July I 983 ; interview with Walter and Margaret Moorman, I4 July I 983 .

45. Quoted from: Henderson, interview; Walter and Margaret Moorman, interview. See also Fishback, "Employment Conditions", pp. I 82-229; Ronald D. Eller, Miners, Millhands, and Mountaineers: Industrialization of the Appalachian South, I880-1930 (Knoxville, TN, 1982), pp. $I 78-182$. For recurring reports of black casualties, see "Six Miners Killed in Explosion at Carswell”, Bluefield Daily Telegraph, I9 July 1919; "Gary (Among the Colored People)", I I December 1923; "Compensation for Six Injured Miners", Io December I923; "Russel Dodson Killed Monday by Slate Fall”, I 4 July I 925 ; "Walter McNeil Hurt in Mine”, 22 July 1925 , all in the Welch Daily News; "Negro Miner is Killed at Thorpe", I 2 June 1929; "Colored Miner Killed Friday in Slate Fall", s March I930; "McDowell County Continues Out in Front in Mine Fatalities", 24 July 1929; "Negro Miner Electrocuted in Tidewater Mines", 9 October 1929; "Hemphill Colored Miner Killed in Mining Accident", 8 January 1930, all in McDowell Recorder. 


\section{COMMUNITY, CULTURE, AND POLITICS}

Under the impact of the expanding bituminous labor force, increasing numbers of black migrants perceived southern West Virginia as a permanent place to live and work. Coalmining was an overwhelmingly male occupation, with few opportunities for black women outside the home. Yet, black women played a crucial role in the settlement of African Americans in the coalfields. Before migration to southern West Virginia during the war years, Catherine Phillips married John Henry, who worked in a nearby sawmill in rural western Virginia. Catherine raised crops for home consumption, performed regular household chores, and gave birth to at least three of the couple's eight children. In 1917, she took care of the family by herself for several months while John Henry traveled to southern West Virginia, worked in the coalmines, and finally returned for her and the children. ${ }^{46}$ Upon arriving in the southern West Virginia coal towns, along with their regular domestic tasks women nearly universally contributed to the diets of their families and the earnings of their men through cultivating, harvesting, and canning the produce of vegetable gardens, including sometimes abundant crops of corn, beans, cabbage, collard, and turnip greens, supplemented by a few hogs, chickens, and sometimes a cow. ${ }^{47}$

As the number of black coalminers and their families expanded, they established their own institutions and launched political movements to secure full citizenship rights and equal treatment in coalmining towns. African Americans developed a variety of class and multi-class institutional and political responses to racial inequality in the Mountain State. While black business and professional men often dominated leadership positions in black institutions, black coalminers, their wives, and other female relatives constituted the core of African-American culture and politics in the region. Predominantly Baptist and African Methodist Episcopal, membership of black religious organizations climbed from less than i 5,000 in the pre-World-War-I years to nearly 33,000 in 1926. Membership of black fraternal orders and mutual benefit societies reached similar proportions, about 32,000, before declining during the late i 920 s.

The emergence of West Virginia branches and affiliates of the National Association for the Advancement of Colored People (NAACP) and the Universal Negro Improvement Association (i.e. the Garvey Movement), the McDowell County Colored Republican Organization, and the black weekly McDowell Times rounded out the institutional life of blacks in West Virginia before the onslaught of the Great Depression. Under the editorship of Matthew Thomas Whittico, a graduate of Lincoln University in

46. Lester and Ellen Phillips, interview by author, 20 July 1983 .

47. In their book of poetry, the Peters sisters illuminated the role of coalfield women's gardening and household activities. See Peters Sisters, War Poems (Beckley, WV, I919), particularly p. 7. 
Pennsylvania, the McDowell Times voiced the civil rights struggles of blacks in West Virginia.

Unlike their counterparts in most southern states during the era of Jim Crow, lynchings, and disfranchisement, African Americans in West Virginia not only gained jobs in the region's major industrial sector, they also retained the franchise. Based on the activities of black men and women, elites and workers, African-American political campaigns produced significant results in the Mountain State. Black coalmining communities not only built an alliance with the Republican Party, they also elected their own representatives to state and local offices. In I 9 1 8, for example, blacks sent three black men to the legislature: the Charleston attorney T.G. Nutter, the Keystone attorney Harry J. Capehart, and, most significantly, the coalminer John V. Coleman of Fayette County. Black legislators spearheaded passage of a state anti-lynching law, a statute barring the showing of inflammatory films such as The Birth of a Nation, and entitlements for the expansion of old and the creation of new social welfare and educational institutions. By 1930, African Americans also claimed access to two state colleges (West Virginia State and Bluefield State); a tuberculosis sanitarium; homes for the deaf, blind, aged, and infirm; schools for delinquent youth; a Bureau of Negro Welfare and Statistics; and an expanding number of public elementary, junior high, and high schools. ${ }^{48}$

\section{THE GREAT DEPRESSION AND AFTER}

During the Great Depression of the I930s, blacks shouldered a disproportionate share of the unemployment and hard times. Their percentage in West Virginia's coalmining labor force dropped from over 22 per cent in I930 to about I7 per cent in I940. The depression and World War II also unleashed new technological and social forces that transformed the coal industry, and stimulated massive out-migration in the postwar years. Loading machines rapidly displaced miners during the I940s and I950s. Black miners recall that the mine management always put the loading machines first where blacks were working. ${ }^{49}$

Mechanization further decimated the black coalmining labor force. The percentage of black miners in West Virginia dropped steadily to about I 2 per cent in 1950, 6.6 per cent in 1960, and to 5.2 per cent in 1970. By 1980, African Americans made up less than 3 per cent of the state's coalminers. To be sure, the white labor force had also declined, dropping by nearly 36 per cent, but the numbers of black miners had declined by

49. Lewis, Black Coal Miners in America, p. 170. 
over 90 per cent. Under the leadership of John L. Lewis, the United Mine Workers of America adopted a policy on technological change that reinforced the unequal impact of mechanization on black workers. As Lewis put it, "Shut down 4,000 coalmines, force 200,000 miners into other industries, and the coal problem will settle itself." $5 \circ$

As West Virginia's black coalmining labor force declined, racial discrimination persisted in all facets of life in the Mountain State. In I96I, according to the West Virginia Human Rights Commission, most of the state's public accommodations - restaurants, motels, hotels, swimming pools, and medical facilities - discriminated against blacks. Most importantly, as blacks lost coalmining jobs, they found few alternative employment opportunities. The state's Human Rights Commission reported that, "Numerous factories, department stores, and smaller private firms had obvious, if unwritten, policies whereby blacks were not hired or promoted to jobs of importance or positions in which they would have day-to-day contact with white clientele." ${ }^{\mathrm{I}}$

Many coalminers and their families moved to the large metropolitan areas of the north-east and mid-west. Small networks of West Virginia blacks emerged in cities such as Cleveland, Chicago, Detroit, and New York. Others moved to the nearby Upper South and border cities of Washington DC, and Alexandria in Virginia. Still others moved as far west as California. Indicative of the rapid outmigration of West Virginia blacks, the state's total AfricanAmerican population dropped from a peak of 117,700 in 1940 to 65,000 in 1980, a decline from 6 per cent to 3 per cent of the total. The dwindling number of African Americans who stayed behind struggled to maintain black churches, newspapers, and other community-based institutions.

In I988, the First Baptist Church of Charleston hosted the First Annual Conference on West Virginia's Black History. Spearheaded by the Alliance for the Collection, Preservation, and Dissemination of West Virginia's Black History, subsequent annual conferences have featured a variety of papers, speeches, and comments on the state's black heritage. They have also reflected an enduring commitment to African-American institutions, values, and beliefs in southern West Virginia in particular and West Virginia in general. Mountain State blacks not only struggled to retain their own institutions, they also joined the Miners for Democracy, an interracial rankand-file movement against the growing anti-democratic impulses within the leadership of the United Mine Workers of America. But the industrial era had slipped away without a viable economic alternative to fill the void left by the departure of "king coal".

50. Dix, What's a Coal Miner to Do?, p. I60.

5. See Joe William Trotter, Jr, "Historical Afterword”, in Ancella R. Bickley and Lynda Ann Ewen (eds), Memphis Tennessee Garrison: The Remarkable Story of a Black Appalachian Woman (Athens, OH, 2001), pp. 223-224. 


\section{CONCLUSION}

Characterized by enduring patterns of class, ethnic, and racial conflict and inequality, the history of the US coal industry represented not one but many stories. The first generation of British and diverse English-speaking miners emerged at the pinnacle of the early coalmining workforce as skilled craftsmen, supervisors, and managers, while the later arrival of new immigrants from southern, central, and eastern Europe entailed an uphill battle breaking into the coal industry, first as coal loaders, and later as supervisory and managerial employees. But it was the color line that defined the staunchest barriers blocking the upward mobility of workers in the US coal industry. Even so, black coalminers' experiences varied from region to region and within the same locale.

Few blacks found jobs in the northern anthracite region and only small numbers entered the bituminous fields of the north and mid-west. By contrast, large numbers of black workers entered the southern Appalachian coalfields of Alabama and West Virginia. In Alabama, many black miners labored as convict workers alongside a free labor force that was itself racially divided between blacks and whites; the latter gained access to a formally instituted wage scale that paid them uniformly higher wages than their black counterparts. In southern West Virginia, black and white workers received the same wage for performing the same work, but Mountain State black miners nonetheless faced ongoing difficulties in using their union card to move around and obtain work during downturns in the coal economy.

Despite important regional and subregional differences in the coal industry, African-American coalminers not only joined the UMWA, they also forged their own communities in the face of different levels of economic inequality, institutional segregation, and discrimination. These highly organized black workers' struggles for freedom and equal rights gained their greatest expression in the southern Appalachian coalfields, but they also characterized life in the northern and midwestern fields. In the years after World War II, as increasing mechanization and de-industrialization undercut the coal-loading workforce, black coalmining communities declined at a faster rate than their white counterparts. Those who stayed in the coalfields built upon the institutional, political, and cultural foundation established by miners during the industrial era. At the same time, they forged new social struggles within the emerging context of the post-industrial era. How well they ultimately succeed in rebuilding their communities and modes of solidarity is yet to be seen. In that, the color line continues to persist. As in the past, this line is both tenaciously sharp and, at the same time, varyingly dotted. 